\title{
Questioning the Border in Yoko Tawada's Poetics of Trans-Formation: Akzentfrei (2016) and Ein Balkonplatz für flüchtige Abende (2016) ${ }^{1}$
}

Eriberto Russo

Suor Orsola Benincasa University of Naples

\section{Introduction}

Yoko Tawada is among the major exponents of the so-called Chamisso-Literatur. This represents a literary designation which echoes a German literary award, the Chamisso-Preis, and which embraced, at the beginning, the identity of non-Germanspeaking authors who wrote in German. Nowadays, as the social landscape of German-speaking countries has changed and we deal with German authors with migratory backgrounds, the definition has transformed its criteria and targets and is starting to be fully integrated into the framework of German canonical literature (Schmitz 2009), while removing the idea that texts written by migrants are to be considered as non-German books (Joachimsthaler; 2009, p. 19).

Tawada was born in Tokyo. After studying Russian literature, she went to Germany, where she achieved a Ph.D. in German

I As there will be many quotations from the German original texts by Yoko Tawada, which have not been yet officially translated, the author of this article will perform all the translations. These latter must not be considered as the official translations, but rather as a way to make the German quotations linguistically intelligible for all readers. Where possible, rhymes and puns have been translated as well. The original text will be included in the footnotes.

How to cite this book chapter:

Russo, E. 202I. Questioning the Border in Yoko Tawada's Poetics of Trans-Formation: Akzentfrei (2016) and Ein Balkonplatz für flüchtige Abende (2016). In: Jonsson, H., Berg, L., Edfeldt, C. and Jansson, B. G. (eds.) Narratives Crossing Borders: The Dynamics of Cultural Interaction. Pp. 75-98. Stockholm: Stockholm University Press. DOI: https://doi.org/IO.I6993 /bbj.d. License: CC-BY 4.0 
literature and where she currently lives. She writes in both German and Japanese; it must be underlined that the present chapter does not take Tawada's production in Japanese into account, but only her production in German. From end to end, her production oscillates between narratives and essays, and makes full use of both ordinary and surreal aspects. The starting point of her writing is the common side of ordinary life, whose meaning she virtually negotiates through the encounter with the surreal. It is in the very moment of that collision that we find ourselves immersed in a narrative flow, which happens to be located on the border between these two domains. The liminal and marginal spaces become, in this way, the dialectical device through which texts transform and translate themselves and land in remote places that, progressively, turn out to be fragments of otherness.

The present contribution will start from these conceptual premises, while exploring some paradigmatic texts in Tawada's production (Slavia in Berlin, Akzentfrei and Ein Balkonplatz für flüchtige Abende), through which the problematic nature of the border space, to which she dedicates many of her reflections, is made more explicit. The methodological debt to the so-called spatial turn (Arias and Warf 2009), an approach that identifies, both in indoors and outdoors places and in mobility, a point of necessary intersection, represents a fundamental starting point. Tawada's texts that have been here taken into account move themselves, in fact, through the dimension of transculturality (Welsch 2002) and depict spatial physiognomies, which reverberate methodologically, moreover, with border theories, which investigate the concept of the border in geographical (the physical and political border), literary (the border as a threshold, a limit etc.) and interdisciplinary (the border in the arts and media) perspectives (Schimanski and Wolfe 2007) and provide important theoretical tools for the present examination.

The investigation of Tawada's perception of the border anticipates the analysis of the poetry Slavia in Berlin, in which the author exploits the full potential of delocating and relocating places in order to structure a sophisticated language game. The reflection opens, on the one hand, to a metalinguistic and metapoetological writing (Akzentfrei) and, on the other hand, to an 
experimental text with a difficult identification from the point of view of the literary genre (Ein Balkonplatz für flüchtige Abende). In Akzentfrei, the emphasis is placed on the border as a metalinguistic space and in Ein Balkonplatz für flüchtige Abende the focus shifts to the text's foreplay, which, in addition to representing a paratextual figure (Genette I987), also constitutes a fluid passing space into the narrative universe.

\section{Talking from the Border: Yoko Tawada's Rede zum Kleistpreis}

Writing an essay on Yoko Tawada's conception of the border means confronting, first of all, an author whose writing process has been said to be rooted in the ravine of language (Slaymaker 20IO) and at the crossroads of languages (Braun and Valtolina 20I6). We do not only deal with the so-called "in-between space" of the language, as this would provide a definition and a location-this is not something we can do with Tawada, as she herself refuses any categorization. We could rather say that her writing overlaps cultures and cultural forms, which, while continuing to keep their characteristics, evolve through new and unexpected forms. In other words, her condition as a writer from another "world" is, this way, initially imaginable as a boundary. The essential point is but, that, for Tawada, there actually are no boundaries, or rather, there can be no boundaries. When critics try to define her writing persona through the word Grenzgängerin - literally "boundary-goer", they collide with Tawada's will not to be defined. The dimensions of the amorphous and of the undefined are the territories she likes to visit and to inhabit. Her entire work can be seen as the presentation of a tendency to refuse to be locked into any category, which she, nevertheless, cannot escape. In support of the ambivalence of these attitudes, we need to remember the acceptance speech she gave during the award ceremony of the prestigious Kleistpreis in 20I6. One of the themes she treated was in fact the border: "At the word boundary, however, I often flinch. It reminds me of armed soldiers"2 (Tawada 2016a).

2 "Beim Wort Grenze zucke ich aber oft zusammen. Es erinnert mich an bewaffnete Soldaten”. 
Tawada recovers from her memory the image of armed soldiers at national borders and adds that her idea of the boundary has not changed since her first journey to the Soviet Union, which later brought her to Germany. The neuralgic point of her reflection is clear in the statement "Between two languages, on the other hand, I never saw a border"3 (Tawada 20I6a). This image refers to the condition of an exophone speaker-someone who lives between languages and throughout languages-who does not question the existence of a border or boundary as he/she himself/herself represents the boundary (Arndt, Naguschewski and Stockhammer 2007). "Each language forms an interspace, and the space between two languages is not a space, but the real space in which literature is written." 4 (Tawada 20I6a). In this latter statement, however, the true meaning of the concept of Zwischenraum-in-between space (Bhahba I994; Wirth 20I2) —comes to light, in the very form in which it is regarded and presented throughout Tawada's production. We can conceive it from two points of view: it can be considered as the blank space between two languages or cultures, or as the diversifying element of a language. On the one hand, we have a Zwischenraum which is built into the language itself, and therefore can have the aspect of a perennial intermediary. On the other hand, we find the space between two languages, which should not be identified as an in-between space, but rather as the place where artistic creation can manifest itself. The author's identity, which is questioned, lies not only in the fracture between languages but also in the point of disjunctiveness between individuality and extraneousness, even if identities, after all, never come to a true conjunction. They rather wander and fluctuate like the soul, which Yoko Tawada describes in her tale Erzähler obne Seele (I996). The absence of the soul, or rather its loss, becomes the starting point for the author and organizes itself as the primordial expression of a lack that finds room also in writing. The inability to recognize the deepened fractures between forms and contents leads to an inquiry that questions the nature of the dynamics underlying the writing itself. The shattering of certainties linked

3 "Zwischen zwei Sprachen hingegen habe ich nie eine Grenze gesehen".

4 "Jede Sprache bildet einen Zwischenraum und der Raum zwischen zwei Sprachen ist kein Zwischenraum, sondern der eigentliche Raum, in dem Literatur geschrieben wird". 
to the power of writing and the processes leading to it makes it possible to open the quaestio to a further consideration. If writing is the result of a fracture between the languages and the nature of the writing itself, where is it possible to conceptually locate the author's figure? It is, perhaps, drawn from the inescapable swirling of the Zwischenraum, which settles itself as the medium through which the structures both of the intermediary and of the boundary come to terms with the dimension of the fictional word.

\section{On the Non-Existence of Places}

"I look like a person without a soul, because my soul is always uprooted." 5 (Tawada I996, p. 20)

After introducing the places in which Tawada's work conceptually takes place, we will see how her way of conveying the instance of authorship actually affects her writing about otherness. On the occasion of a conference in San Francisco, she held a talk entitled "Tawada Yoko does not exist". Thanks to a kind of uninterrupted and uninterruptible "sleight of hand" with her own work and her persona, Tawada makes it possible to consider her as an example of what I would now like to begin describing as the "staging of a border of otherness".

In one of her most famous tales, which we can find in the volume Talisman (I996), Tawada points out in first person, as though confessing a secret, that she has been deprived of her soul. From that moment on she has actually become the Erzähler obne Seele (Tawada I996, p. 20) - a storyteller without a soul — of which she talks about in her aforementioned tale. The latter question is something that we can circumscribe as a multiform privation that occurs through the most unlikely ways and that is strictly linked to cultural dimensions such as the Western and Eastern worlds, that are, in her personal life and writing experience, so close together. It is Tawada herself who constantly questions the possibility of speaking of a diametrical conceptual opposition

5 "Ich sehe aus wie ein seeloser Mensch, weil meine Seele immer unterwegs ist". 
of the East, from which she herself comes, and the West, which welcomed her. These ways of conceiving of otherness represent objections that are frequently raised since they are primarily related to the concept of belonging. Where does she, actually, belong? The author herself tries to give an answer in the incipit of Sprachpolizei und Spielpolyglotte (2008).

I am in Europe. I don't know where I am. One thing is sure: the nearest East is very near from here, too. The place, from which the nearest East very near is, is named Europe. When I still used to live in the far East, the nearest East was very far. ${ }^{6}$ (Tawada, 2008, p. 2I)

In the core of her reflection, there is a presumable dismemberment of the concepts of proximity and distance, of both East and West. Tawada claims to be in Europe, but at the same time she denies this with a geographical recognition. In order to escape the feeling of disregard for Europe, where her body should theoretically be, Tawada finds shelter in an attempt to redefine the geographical categories of the Near East and the Far East. Since the first effort to locate Europe fails, she leads her own investigation to the extreme by introducing the figure of the airport, which the French thinker Marc Augé has included in his list of the non-lieux (Augè 2009). By bringing it back to her recent experience, she declares that she has observed the departure and arrival schedules of the planes and has produced a kind of solution: the essence of Europe lies in the places where the planes land. She denies, even so, a real value to this other solution since sometimes planes do not land as expected where they are supposed to land (Tawada 2008, p. 23).

In addition, Talisman is very important because it is possible to find a poem entitled Eigentlich darf man es niemandem sagen, aber Europa gibt es nicht, in which Tawada had already given her final judgment on the existence of Europe. Europe does not exist, but it is necessary to silence this truth. This continent is localized on a geographical map but can be found neither in the mind nor

6 "Ich bin in Europa. Ich weiß nicht, wo ich bin. Eines ist sicher: der Nahe Osten ist von hier aus ganz nah. Der Ort, von dem der Nahe Osten ganz nah ist, heißt Europa. Als ich noch im Fernen Osten lebte, war der Nahe Osten ganz fern". 
in the soul. We should not, however, be upset by such a dissection of what should be geographically unitary. Theoretical attempts to locate, in Tawada, are often imbued with an ideological lust for a delocalization (Ottmar 20IO, p. 22I)

When I wrote in a poem that Europe does not exist, I did not mean that it was lost. I wanted to argue that Europe was already invented as a lost figure. ${ }^{7}$ (Tawada I996, p. 50)

Tawada does not want to create ambiguity. It is not possible to define this loss in relation to an earlier existence of Europe. The loss of which Tawada speaks is an a priori loss, a real absence of identity, born with Europe. This is an aspect which sheds light on another central issue in Tawada's conception of places. The European continent, as well as other places, is to be seen as a basic object of interest, which can be summarized through some elementary questions. What is a country and what is, moreover, a place? They can be considered both as simple points on the geographic map to which a particular nomenclature is tied, or they can be entirely questioned. Tawada chooses this second option.

She offers, in fact, an interpretation of the concept of land in the poem that opens the volume Sprachpolizei und Spielpolyglotte. The poem is titled Slavia in Berlin. The peculiarity of this poem is to be found in the total violation of both the dimensions of significance and meaning. The composition is told from the point of view of a traveler who is wandering to reach someone with whom she has a close and perhaps sentimental relationship that is endangered by the distance.

Slavia in Berlin shows a particular and unusual use of vocabulary. Everyday words are replaced and, at various moments, interrupted by place names. Such a technique seems, however, to be unconscious. It seems, in fact, to flow naturally into the mind of the narrator.

7 "Als ich in einem Gedicht schrieb, dass es Europa nicht gibt, meinte ich auf keinen Fall, dass sie verlorengegangen sei. Ich wollte eher behaupten, dass Europe bereits im Ursprung als eine Verlust-Figur erfunden wurde. The so mythical idea of a Europe and so often talked about and celebrated is actually born as a figure of the loss." 
I took Abu Simbel from my Cameroon and left Los Angeles

Appointed at three o' clock $^{8}$

(Tawada 2007, p. 7)

The places that Tawada mentions throughout the poem are rather disparate; we can find, in fact, known, unknown, urban, rural, contemporary, ancient and exotic locations. Through their employment, the author intends to create a discourse revolving around a dialectic of spatiality, the relocation of something which cannot be apparently located (since it does not exist) and that aspires to survive in the ordinary language only through a statement of the impossibility to locate itself.

In the first three lines quoted, it is possible to recognize three main sites: Abu Simbel, Cameroon and Los Angeles. In a phonetic space of about 25 syllables, the reader is brought to his knowledge on two continents, Asia and Africa, and two epochs, antiquity ${ }^{9}$ and contemporaneity (Mousel Knott 20IO, pp. 40I-404). A reader who is well acquainted with the German language will identify the inclusion in the first line of a grammatical agreement that could be understood as an apparent mistake, namely von mein Cameroon, which should have been von meinem Cameroon. The mistake is however intentional, as, in the context of an oral reading, the plural form of the dative in its phonetical reduction is able to recreate the articulatory atmosphere of the expression von meinen Kammern. Every word, every sound and every single constituent element of a sentence or line of poetry plays a role in the overall context and has to recall another element, which must be equally significant and at the service of the senses: this is due to the presence of an infinite creation of intertextual links. It is possible to raise, nonetheless, a question in relation to the associations that the author constantly uses. In the case of a poem like Slavia in Berlin, it cannot be said that the piece of information that each element mentions is immediately clear to every type of reader. An average, educated individual might not know the cultural value of

8 "Ich nahm Abu Simbel von mein Cameroon und ging Los Angeles, verabredet um drei Uhr".

9 Abu Simbel is an archeological site, whose importance is strongly related to the antiquity. 
a place of worship like Abu Simbel, but he or she might know Los Angeles and Cameroon; in the case of a complete lack of intelligibility with respect to the places mentioned in the poem, the author ensures and incites a sort of collapse of all links by reducing the locations to simple letters.

\author{
I was in $\mathrm{K}$, too \\ I will be in $\mathrm{G}$ \\ You will be in $\mathrm{T}^{\text {เo }}$ \\ (Tawada 2007, p. 8)
}

Another method of deconstruction is the reduction of the localities to contracted and easily recognizable shapes.

\title{
In California you were a deer in San F., in San D II
}

(Tawada 2007, p. 7)

It is at this point that the idea of a total deconstruction of the spatiality materializes itself at its best and through an idea of a space that can be both filled and possibly blackened or, categorically, dodged. The intertextual and hypertextual quality of the poem extends while embracing the hermeneutic activity in its entirety. The reader is called to contribute actively to the development and the melting of the interpretative knots of the text. It must, actually, face a poetic voice that is totally unaware of the grammatical and lexical transgressions it is making. Tawada, as the author, is certainly conscious, in contrast to the poetic voice, which is not. The question arising from these reflections is mainly linked to the role of the act of reading. How does one come to terms with the inability of the poetic voice to recognize its transgressions? The reader is certainly called, in an elementary way, to read the whole poem in order to understand its meaning and to investigate its own impressions. After the reading process has ended, you have, of course, to recapture in your memory and in your individuality the meaning you have tried to give while constructing its horizon of analysis. The reader must understand, with a deeper and more technical gaze, how the poem relates to itself and which

\footnotetext{
ıо "Ich war auch in K. / Ich werde in G. sein/ Du wirst in T. sein".

г "In California warst du ein Reh/ In San-F, in San-D”.
} 
narrative devices inspire it. This may, of course, apply to any type of experimental poetry, which, as in Tawada's case, wants to present in the purest and most concrete way the idea of a polyglot game, or a Spielpolyglotte. However, we need to go back to the first lines of poetry in order to make an important observation. It has been said how much the name of each place is central to the understanding of the poem's message. Nothing is left to chance; the name of each appropriately reduced phonetic site can be attributed to an expression or to a German word. By practicing this rule, we would see that "Ich nahm Abu Simbel von mein Kamerun und ging Los Angeles verabredet um drei Uhr" could be reformulated in the following way: "I left my rooms and went away, appointed at 3. ." I2 Likewise, while reading, we come across other places, the names of which we can almost immediately correlate to some words in German:

\section{Cigarettes were Heilbronn \\ Ticket machines were Cape Town \\ The machine did not take my Europe, neither Munich nor Shines ${ }^{\mathrm{I3}}$ (Tawada 2007, p. 7)}

This unceasing self-staging through wordplay provokes a brief moment of bafflement. Is there, then, another place behind each place, another space to be filled, a place to recognize and interpret? Let us take for example Heilbronn and Kapstadt. Behind the two cities, it is not difficult to recognize the adjectives heil and kaputt, which could virtually replace the names of the two cities. If, from a lexical point of view, behind the city of Munich it is possible to identify the term Münzen, a somewhat more complex role is played by the use of the term Europa, which, in this case, experiences a true reification by becoming a thing-perhaps a banknote-that the machine cannot read. The experiment opens up, in this way, into a sort of trespassing labyrinth. Places, cities or continents, of any size and extension, are like objects to be grasped. The grammatical categories hiding behind the place

\footnotetext{
${ }^{\text {I2 }}$ "Ich nahm ab von meinen Kammern und ging los, verabredet um drei Uhr”.

I3 “Zigarettenautomaten war Heilbronn/ Fahrkartenautomaten waren Kapstadt/ Die Maschine nahm meine Europa nicht an /weder München noch Scheine”.
} 
names are various; the name of a city or a land indicates a noun, an adjective and sometimes other interjections or conjunctions.

\section{Sinai, Sinai, you can find here no Prague \\ Bathu Dhabi, I need to go to Prague ${ }^{\mathrm{I4}}$}

(Tawada 2007, p. 7)

In a conversation between the first-person narrator and the Texasfahrer, the misunderstanding takes over when the woman asks to go to Prague. The Texasfabrer-the term behind which is hidden Taxifahrer-is confused and responds negatively by replacing Nein with Sinai. The repetitions of the term Prag, at the end of the two verses, fits inside an unreported dialogue, which sees the city Abu Dhabi as a replacement for the conjunction Aber. The entire poem is crossed by this replacement technique. By lexically scrutinizing the text we find other consonances such as Finnland_Finden, Ägypten-Gibt and Lassen Sie mich dann hier Australien-Lassen Sie mich dann hier aussteigen. This geographical discourse runs out towards the end of the poem, even if not completely, with a sudden change of register. The ironic alternation of city names and misunderstandings are replaced with a more melancholic tone. The first-person narrator does not forget her goal, which is the appointment with a lover, introduced through the personal pronoun you: "I have described you the wrong place. You told me." "s The monolingualism is abandoned in order to give space for a dialogue which moves from a focus on me to us: "We found the brightest table without a city map." ${ }^{6}$ The sentimental element breaks into the narration as the meeting starts to take shape and ends by concluding the poetic project, which takes on dramatic tones.

Crawling on the ground I look for the clock second hand, which has fallen out of my mouth. What is the name of the city that never ends?

Its first syllable does not occur to me

${ }_{14}$ "Sinai, Sinai, Sie finden dort kein Prag! / Abu Dhabi, ich muss nach Prag!"

${ }_{15}$ "Ich habe Dir den Ort falsch beschrieben, sagtest du zu mir."

i6 "Den hellsten Tisch am Fenster fanden wir ohne Stadtplan." 
In its place begins your absence. ${ }^{17}$

(Tawada 2007, p. 9)

This way, the required blank spaces and the distortions of the localization take the form of an absence, or better said, of a lack of memory. After having quoted and virtually visited so many places and traveling metonymically between continents and countries, the first-person narrator shows a mournful tiredness. She wonders what the name of the city is which does not end and suggests that she is not even able to remember the first syllable. At the same time, she declares the end of the searching process. The quest for the place, that cannot be found, is, consequently, replaced by the nonappearance of the beloved. The curtain falls, the light goes off and the public Ab-Laus (ap-plause). Everything goes back to normal, the interlocutor goes away and returns to its own hideout and the narrator, tired from the long and hard journey and confused by the unsolvable research of the places, starts a further journey towards the station Nirgendzoo, behind which hides the final declaration of non-existence, actually a Nirgendwo (nowhere).

\section{Infringing the Perception of Spatial Border: Akzentfrei and Ein Balkonplatz für flüchtige Abende}

As we have seen, places play a central role in Yoko Tawada's poetics, which Christiane Ivanovic (2010) defines as a poetic of transformation, by expecting this concept to be the description of the whole work written by Tawada. The author, in fact, has, on more than one occasion, described her intellectual debts to both Ovid and Kafka, as she manipulates the transformative quality of the language in order to transform and decentralize physical, perceptual and mental places.

The spaces that the author brings into play are not only to be considered as belonging to the geographical domains, but to the mental and poetic ones as well. In Tawada's writing dimension, everything can configure itself as a place, which by employing

\footnotetext{
${ }_{17}$ "Auf dem Boden kriechend suche ich nach dem Sekundenzeiger/ der aus meinem Mund gefallen ist. / Wie lautet der der Name der Stadt, der nie endet? / Seine erste Silbe fällt mir nicht ein. / An ihrer Stelle beginnt schon deine Abwesenheit”.
} 
at most the pervasive quality of the boundaries, outlines itself as a way to conceive the space of the transformation. The author's last two works, Akzentfrei and Ein Balkonplatz für flüchtige Abende, both published in 2016, fit within the complex and dialectical overcoming of both the category of the border and the act of trespass.

\section{Akzentfrei (2016): On Languages and Edges}

Akzentfrei is considered, as the back covers show, to be a continuation of the collection of essays put together in the Talisman (I996) and was published in 2016, exactly twenty years after the publication of the aforementioned Talisman. Akzentfrei gathers in itself all aspects of poetics, which have, over time, succeeded in exploiting the ubiquitous transformation characteristic to which Tawada's poetic texts are subject, in order to transform themselves. The volume is divided into three parts: In einem neuen Land, Nicht vergangen and Französischer Nachtisch. In the first section, to which I will turn my attention, Tawada resumes some of her production themes, namely, the accent, the Trans-Siberian location and the problems of writing and translation, placing them in dialogue with the virtual configurations of modernity. By accompanying readers on an imaginary journey between the forms and the drifts of extraneousness, Tawada describes, or rather, deepens her metapoetic project, which becomes summarized in the title of one of the stories in the volume: Schreiben im Netz der Sprachen. Tawada's writing is not about melancholy and a lack of a country of origin, but is a critical reflection on being foreign in a country, in fact, foreign. Daily and surreal dimensions overlap, creating new forms and translations of identity. The encounter of the surreal with objects drawn from the sphere of everyday life leads to a semantic enhancement of the space of writing.

The title of the Akzentfrei volume refers to several issues related to her production and shows, while trying to translate it, different levels of confrontation with otherness. We might translate it as "without accent", "free from accent", or "released/freed from accent". In the first case, "without accent", we would point to the lack of accent in a certain word. This aspect is impossible in German, since non-ideological languages, as Tawada stresses on several occasions, base their existence on rhythm. In the 
second and third cases, "free or freed from accent" would mean emancipation from the formal characteristics of the language itself (accent, pronunciation, rhythm) and consideration of language as a visible object. "The accent is the face of the spoken language" I8 (Tawada 20I6b, p. 24). By meeting the visual object-das Gesicht-with the acoustical aspect-der AkzentTawada casts the foundation for further writing on identity, that of a figure seeking a space for oneself in everyday life. Talking, just like traveling, means drinking "foreign water". This is a topos that often comes back in Tawada's texts, almost as an interpretative formula of the condition of otherness in its entirety. The accent is audible just as the face is visible; if the exterior appearance carries the traces of the time passing and facial expressions point to the mood, the accent is a trace of one's own sound identity. Any alteration and deviation from the socially accepted norm, which dictates that words must be pronounced in a certain way, or with a specific accent, should not be identified as a reason for discrimination or as an inability to speak properly a language, but rather as an invitation to create: "It is not my task to distinguish between a regional coloring, a foreign accent, a sociolect and a language error." 19 (Tawada 20I6b, p. 24). What does it mean to deviate from the norm and to take advantage of the deviation in order to make poetry? Tawada explains her point by describing an everyday situation. If we find ourselves at a restaurant during lunchtime, we might face, through a dialogue or a passive listening of the voices around us, an encounter with other accents or with other landscapes. When a presumably foreign waitress would begin to speak, her words would start floating around in the air and transform themselves into something different. In that very moment the waitress and her accent are inviting us to see distant places through her mouth.

The author tells us about an imaginary expedition beginning on an equally imaginary Orient Express: "Her breath is an Orient

\footnotetext{
I8 "Der Akzent ist das Gesicht der gesprochenen Sprache".

19 "Es ist nicht meine Aufgabe, eine regionale Färbung, einen ausländischen Akzent, einen Soziolekt und einen Sprachfehler voneinander zu unterscheiden."
} 
express. I get on.” ${ }^{20}$ (Tawada $2016 \mathrm{~b}$, p. 24). If, on the one hand, the accent can be seen as a cause for discrimination, since it is subject to negative assessments, on the other hand, the impulse to integrate and to keep alive the inevitable Zwischenraum emerges from the crevices between the different identities and the various lives of a foreigner. The contrasting feeling of mixed fear and desire to be or become someone else through interaction with the otherness emerges in the reflection on the accent, contained in the story Schreiben im Netz der Sprachen. While recovering the formulas of Zwischenraum and Exophonie, Tawada employs the metaphor of the web in order to explain how writing should be intended as a result of an interaction: "When I came to Europe I had burning questions in my luggage: will I become another person, when I speak another language?" ${ }_{21}$ (Tawada 20I6b, p. 29). Some moments of the biography of Tawada have become the subject of an epic process. The arrival in Europe is one of them. In the quoted statement, which summarizes the insecurity and curiosity of living a lifetime, the author questions the experience of residing in a foreign country not only in its material aspects but also in its spiritual consequences.

The act of interrogating one's own destiny, face, accent and language is used as an excuse to come to a conclusion. The individual must be considered to be a network that is progressively encouraged to create new interpretative models for the self and for the world. We deal with a network that resembles a new body, as it has bones, cavities and ends, which, combined with the knowledge, give birth to a new self. In this new reticular form, writing is engraved-it is a mixture of words, which on the one hand, remain in a web in the vice of the impossibility of a profound understanding, and on the other hand, exploit the network itself to "define" and become autonomous. To illustrate this aspect, Tawada uses the term Wortspielerei, which, in her opinion, dialogues with the space-time overlapping, in which the individual acts.

20 "Ihr Atemzug ist der Orient Express. Ich steige ein."

${ }_{21}$ "Als ich nach Europa kam, hatte ich brennende Fragen in meiner Reisetasche: werde ich zu einem anderen Menschen, wenn ich eine andere Sprache spreche?” 
Why do we have to deal with such a word play? In today's world we can always see words and images from different worlds side by side. Through migration, world travel or surfing on the Internet one finds oneself more and more often in a situation in which the co-existence already exists, without a corresponding thinking space was developed. Sometimes I catch the bus and go through the city and am surrounded by several conversations in different languages. Two sentences, that randomly enter my ears, do not yet have a common space. You need a framework to connect these sentences together. ${ }^{22}$ (Tawada, 20I6b, p. 35 ).

Tawada declares, in a sense, our inability to think of the world as singular, while emphasizing, moreover, the need to think of it in a plural way and not forgetting that each plurality has, in the end, a singularity. In transitioning from an imaginary journey to a real one among the cities, the author notes how different languages and cultures come into contact in places such as on the bus, leading to the creation of new narrative scenarios. This process, continues Tawada, recalls the projects of surrealists that can be considered as the initiators of this Poetik der Wortspielerei (poetics of the puns) produced by a shared design "which could bring a sewing machine together with an umbrella.” ${ }_{23}$ (Tawada 20I6b, p. 36). It is not just surrealists who are referring to the point of reference, but also Goethe, as in one of the poems contained in the Westöstlicher Divan in which the words Wort and Fort create a rhyme. To these two words Tawada adds the word Ort, generating a triad of rhymes that she herself uses to expose the "evocative" quality of the three words: "Every time when I think these three words together, it flashes in my head. Words create places, but in the

22 "Wozu muss man sich mit so einer Wortspielerei beschäftigen? Im heutigen Leben sieht man ständig Wörter und Bilder aus verschiedenen Welten nebeneinander. Durch Migration, Weltreisen oder Surfen im Internet befindet man sich immer häufiger in einer Situation, in der das Nebeneinander bereits existiert, ohne dass ein entsprechender Denkraum entwickelt worden ist. Manchmal fahre ich mit dem Bus durch die Stadt und bin umgeben von mehreren Gesprächen in verschiedenen Sprachen. Zwei Sätze, die zufällig direkt hintereinander in meine Ohren dringen, haben noch keinen gemeinsamen Raum. Man braucht eine Rahmenhandlung, um diese Sätze miteinander zu verbinden.”

23 "auf dem eine Tretnähmaschine mit einem Regenschirm zusammenkommen konnte." 
place where one is located, one is always already gone" ${ }^{24}$ (Tawada $2016 \mathrm{a}, \mathrm{p} .36)$. The perception produced by thinking of words that are similar in sound but not in meaning leads the author to invest the individual terms with a new semantic valence, with the purpose of producing an effect of strangeness. Only through surreal alienation, which virulently defies the order of things, is it, in fact, possible to generate definitions; words have evocative power when they find themselves on the space of the page. The evocation produces a place that does not necessarily correspond to the one in which it is located.

\section{Ein Balkonplatz für flüchtige Abende (2016): The Foreplay as Introductory Border}

With Ein Balkonplatz für flüchtige Abende, Tawada's narrative experimentalism reaches high levels of both authorial and interpretative opacity. This text is part of that new moment of Tawada's poetics which we can now try to define as a "poetics of water", and which appears to be a development of the already problematic "poetics of transformation". It is not meant as a change of course, but simply as a narrative sophistication of the metamorphic dimension. The water, the amorphous figure par excellence, becomes a new motif to which we turn our gaze in order to outline the narrative features of Tawada's last works. This new phase of her poetics, initiated properly with the publication of the volume Fremde Wasser, is the result of a series of lessons held in the framework of the Hamburger Poetikvorlesungen in 2012, and is basically taken from a revealing sentence that Tawada often uses, in which she sees the journey as a time of contact with foreign waters (Tawada I995, p. I).

Like most of the works by the Japanese-German author, the text moves through polyvalent territory. On the one hand, we find the daily dimension, on the other hand, the surreal dimension. The encounter, which can sometimes be seen as a critical crash, leads to a great inferential effort for the reader. Departing from the traditional classification of the literary genres, Tawada's last

${ }_{24}$ "Jedes Mal, wenn ich diese drei Wörter zusammen denke, blitzt es in meinem Kopf. Worte schaffen Orte, aber an dem Ort, an dem man sich befindet, ist man immer bereits fort." 
work could be identified both as a poetic novel and as a fiction of poetry. Such definitions, the result of a play on words, define the author's space of action, which never moves only within in a genre, but alters the very concept of literary categories while overcoming formal boundaries. It is precisely this aspect that leads us to distance ourselves from the rules and to construct a discourse about the infractions.

The text is composed of I4 narrations in verse and opens with a kind of prologue, to which the author gives the name of Vorspiel (foreplay), a name which indicates, in the theatrical lexicon, an anticipatory moment. Such a foreplay is, as we will see, an important narrative feature.

Revolving around a space-time dimension that can be traced in the free space between the theatrical and the poetic surface, the work moves around the anthropomorphizing of the forms, in which all that is watery manifests itself, including the river and the sea, and comes to revise and rethink the figure of the siren, which acts as a glue and as an emblem of the encounter between the sea and the terrestrial space.

In the Vorspiel, where the dimension of liminality is both physical and conceptual, we witness tight processes of lexical associations that, however, do not always produce a meaning. This latter aspect makes it possible to configure Tawada's work as an open work which does not incorporate formal and mental limitations, and which crosses all possible boundaries (Eco 2000).

By taking advantage of its changing identity, borrowed from the maritime dimension, Ein Balkonplatz für flüchtige Abende succeeds in overcoming the facet of unintelligibility and acquires, therefore, infringing features. The title, literally "a place on a balcony for ephemeral nights", can be considered to be the place from which it is possible to observe an uninterrupted flow of impressions, thoughts and images. These are destined to break into the primary matter of Tawada's possible worlds, that is to say, the language. Even if we consider a theoretical framework different from that of Akzentfrei or Slavia in Berlin, Ein Balkonplatz für flüchtige Abende is a tribute to the ability of the language to mold and transform itself when in contact with the liquidity of artistic creation. The symbolism of the balcony, which can be seen as a physically suspended place that facilitates an individual's 
contact with the outside, reveals itself in its essence in a form similar to another eye that describes what can be represented as a duel between the pseudo-corporeity of the tongue and the watery amorphism, which, however, proves to be in the overturning of the ordinary into surrealism (Tawada $2016 \mathrm{~b}, \mathrm{p} .5$ ).

The North Sea has longing for the Czech Republic stretches her blue arm into the interior of Europe

[...]

Who pushes the sleeping-clouds/ in the cosmic abacus?

The rehabilitation of the sky goes into the

Length $[\ldots]$

passersby are cleansed

curtains at the window

all traffic lights between $\mathrm{A}$ and $\mathrm{B}$

between Altona and Blankenese

stay out ${ }^{25}$

(Tawada, 20I6c, p. 5)

The foreplay exemplifies, in a nutshell, two collateral processes: on the one hand, the personification of what is inanimate, on the other hand, the surreal reification of what is animated. In this regard, the North Sea, in a nostalgic longing for the Czech Republic, stretches its arms towards Central Europe; the sky is undergoing a restructuring; the passers-by are put in order (note the use of the verb aufräumen, usually used to indicate the ordering of a room or a messy space).

The space of the infraction thus becomes a space in which the sensitive and surreal dimensions overlap, creating a further space where everything flows and trespasses.

As the Elbe-the river flowing in the city of Hamburg and representing the figure around which the text is built-retires, we read of a male speaking voice:

25 "Die Nordsee hat Sehnsucht nach Tschechien, / streckt ihren blauen Arm ins Innere Europas./ [...] Wer schiebt die Schlafleinwolken/ im kosmischen Abakus hin und her?

Die Sanierung des Himmels zieht sich in die/ Länge. /[...] Passanten werden aufgeräumt,

Gardinen am Fenster zugezogen, / alle Ampeln zwischen A und B, / zwischen Altona und Blankenese / bleiben aus.” 
From one of the roses bush speaks to me/

Voice on, male-hoarse'

Hey, you there, can you place yourself there and

control that no one can see me? I need to

What does he have to do?

Have to is an auxiliary verb

which helps no verbs

Watch out? So that no one sees him?

an invisibility service?

The man blinks nervously ${ }^{26}$

(Tawada, 20I6c, p. 6)

From the bush, presumably nearby the river, arises a masculine, slightly gloomy voice, asking someone-probably one of the realigned passers-to check that no one sees it, while giving a reason, introduced by the modal duty verb, without concluding, however, the sentence. From the dialogic form, we return to the narration in the third person. The narrator focuses her attention on the absence of a modal-related verb, which is, therefore, considered to be an auxiliary verb which, in fact, does not perform any auxiliary function-perhaps because it does not belong to it. After the linguistic reflection, we find ourselves, again, in the dialogue between the two characters: the corporal voice becomes ever more nervous and masculine. The reader starts questioning his identity and his purposes: what does he want and what does he expect from his interlocutor? He is, actually, questing for an invisibility, that cannot be realized.

Do you understand German? I have to

Leave the water

There is already enough water, I replied

In the word answer sits a we.

This time it was not him but me.

He's looking at me from hair to

shoe and says:

26 “Aus dem Rosenbusch spricht mich eine/ Stimme an, männlich-heiser. / Hei, du da, kannst du dich/ dort hinstellen und auf-/Passen, damit niemand mich sieht? Ich muss mal. Was muss er? / Müssen ist ein Hilfsverb, dem kein Verb/ zu helfen weiß. / Aufpassen? / Damit keiner ihn sieht? / Ein Unsichtbarkeitsdienst? / Der Mann blinzelt nervös.” 
What! You are a girl!

I would not have thought. Such a shi...! Words hiss in his mouth the slider drives up the pants.

The curtain too and the man

Is swallowed by the rose bush

What did he want from a boy?

who was not me? ${ }^{27}$

(Tawada 20I6b, p. 7)

The demanding tone grows exponentially into an urgent need for communication. The being, which we can now recognize as stranded in the sea, declares to the interlocutor a need to leave the water, and this expression creates a communicative misunderstanding. While the stranded being intends to claim a need to abandon the aquatic space, the interlocutor intends this action to be a "saving" of the water. After this follows the last scene of the foreplay. The identity of the converser is discovered: it is a young girl. This finding leads to the disappearance of the male stranded being, which anticipates this disappearance with an opening of both the encounter and the conversation to possible ambiguous declinations, motivated by the use of the term Knaben (boy) by the young girl. This latter wonders, in fact, what he might have wanted from a boy that, besides, she was not.

The stranded being, which we can now compare to a male mermaid, or a merman, provides the text with the first deep inclusion into the dimension of indecisiveness. The mermaid, usually described as female, is described here as a male. The presumable sexualization process of the girl he is talking to and his following escape reveals that his disappearance is intended to be an echoing and overturning action of the fate of those who came near the mermaids and were attracted by their murderous voices. In this case, when the merman discovers

27 "Verstehst du Deutsch? Ich muss / Wasser lassen/ Wasser gibt es schon genug, erwidere ich. / Im Wort erwidern sitzt ein er. / Dieses Mal war es aber nicht er, sondern ich. / Er mustert mich vom Haar bis zum/ Schuh und sagt:/ Ach was! Ein Mädchen bist du! Das

hätte ich nicht gedacht. So ein Schei...! / Wörter zischen in seinem Mund, / der Schieber/ fährt die Hose hoch. / Der Vorhang zu und der Mann/ Ist wie vom Rosenbuch verschluckt. / Was wollte er von einem Knaben, / der nicht ich war?" 
that the person, he is talking to, is not a boy, he escapes while leaving the girl behind: his voice has not attracted the right human being and his attempt to sexualize and being helped has failed. Only a boy could have saved him from the water.

\section{Conclusion}

Tawada's connection to an emerging parallel German literary canon makes it difficult to attempt any categorization of her work, which she herself eludes by defining her existence as exophone, that is, residing in no fixed place but in one's questionable identity. The ambition to reach an expression of delocalization and a claim of the non-existence of the spatial dimension play, as we have seen, a dominant role in her production: the border expresses, in fact, the elected dimension in which such a narrative ambition finds expression

Three different levels of the expression of the border have been explored in this paper. In Slavia in Berlin, which functioned to introduce the vagueness of the concepts of "places" and "spaces", the border is configured as an expedient through which we come to understand the need to question any location and relocation. In Akzentfrei, we have seen the border as connected to language; the latter has proved to dispose of infinite possibilities of reticular manifestations. In Ein Balkonplatz für flüchtige Abende, the border has been highlighted from two points of view. On the one hand, we have considered the foreplay as an introductory and integral part of the narrative flow; on the other hand, we have seen how the borders shape themselves through the encounter between the ordinary and the surreal, displaying them, in this case, in a challenging relation to the amorphous dimension of the water.

\section{References}

Arndt S., Naguschewski D., Stockhammer, R.(eds.) (2007).Exophonie. Anderssprachigkeit in der Literatur. Berlin: Kulturverlag Kadmos.

Arias S., Warf B. (eds.) (2009). The Spatial Turn. Interdisciplinary perspectives. Abingdon: Routledge. 
Augé, M. (2009). Non-Places. An Introduction to Supermodernity. Brooklyn: Verso Books.

Bhabha, H. (1994). The Location of Culture. Abingdon: Routledge.

Braun, M., Valtolina, A. (eds.) (2016). Am Scheideweg der Sprachen [At the crossroads of languages], Tübingen: Stauffenburg.

Eco, U. (2000). Opera aperta. Milano: Bompiani.

Genette, G. (1987). Seuils. Paris: Éditions du Seuil.

Ivanovic, C. (eds.) (20II). Poetik der Transformation. Tübingen: Stauffenburg Verlag.

Joachmisthaler, J. (2009). "Undeutsche Bücher: Zur Geschichte interkultureller Literatur in Deutschland," in Helmut Schmitz (ed.), Von der nationalen zur internationalen Literatur. Transkulturelle deutschsprachige Literatur und Kultur im Zeitalter globaler Migration, Amsterdam/New York: Rodopi, pp. I9-40.

Knott, M. S. (2010). "External links from Yoko Tawada's Text to a Hypertext Beyond," in Ivanovic C. (eds.), Yoko Tawada. Poetik der Transformation. Beiträge zum Gesamtwerk, pp. 40I-404.

Ottmar, E. (20I0). "Zeichenreiche. Insel-Texte bei Roland Barthes und Yoko Tawada," in Ivanovic, C. (eds.), Yoko Tawada. Poetik der Transformation. Beiträge zum Gesamtwerk, Tübingen: Stauffenburg Verlag, pp. 207-230.

Schimanski J., Wolfe S. (eds.) (2007). Border Poetics De-limited, Hannover: Werhahn Verlag.

Schmitz, H. (eds.) (2009). Von der nationalen zur internationalen Literatur. Transkulturelle deutschsprachige Literatur und Kultur im Zeitalter globaler Migration. Amsterdam/New York: Rodopi.

Slaymaker, D. (eds.) (2010). Yoko Tawada. Voices from everywhere. Plymouth: Lexington books.

Tawada, Y. (2016b). Akzentfrei. Tübingen: Konkursbuch Verlag.

- (2016c). Ein Balkonplatz für flüchtige Abende. Tübingen: Konkursbuch Verlag.

(I996). Erzäbler ohne Seele. in Tawada, Y., Talisman, Tübingen: Konkursbuch Verlag. 
- (2012). Fremde Wasser. Tübingen: Konkursbuch Verlag. (2016a). Rede zum Kleistpreis [Speech for the Kleistprize]. Available at: Url: http://www.konkursbuch.com/html/net\% 2020 I 6 herbst/reden \% 2okleist/yoko\% 2otawada-KleistPreisrede.pdf

- (2007). "Slavia in Berlin," in Tawada, Y. Sprachpolizei und Spielpolyglotte. Tübingen: Konkursbuch Verlag. (I996). Talisman. Tübingen: Konkursbuch Verlag. (1995). Wo Europa anfängt. Tübingen: Konkursbuch Verlag.

Welsch, W. (2002). Kulturverständnis. Netzdesign der Kulturen. In: Zeitschrift für Kulturaustausch. I/2002, pp. 86-88.

Wirth, U. (2012). "Zwischenräumliche Bewegungspraktiken," in Wirth, U. (eds.), Bewegen im Zwischenraum, Berlin: Kulturverlag Kadmos, pp. 7-34. 